\title{
The Power and Authority of Perpetua the Proto-Martyr ${ }^{1}$
}

\author{
ANGELA BRKICH-SUTHERLAND \\ $1^{\text {st }}$ Year, PhD Religious Studies \\ University of Alberta \\ Edmonton, Alberta
}

With the emergence of feminist biblical scholarship, there has been a re-evaluation of the status and participation of women within early Christian communities. Instead of focusing upon texts that support and re-enforce traditional Greco-Roman gender roles, feminist scholars have widened their search to include texts that appear to provide women with roles of leadership and the opportunity to participate in activities that were previously restricted to men. Informed by this methodology, I will examine The Martyrdom of Perpetua and Felicitas and evaluate Perpetua's status and authority within her early Christian community. This method of interpreting the text will permit me to examine Perpetua's status, participation and influence within her Montanist community. ${ }^{2}$

This paper will argue that Perpetua, as described in The Martyrdom of Perpetua and Felicitas, held a position of authority within her early Christian community. First, I will examine the concept of martyrdom within early Christianity and the benefits associated with selfsacrifice. Second, I will examine general textual instructions in The Martyrdom of Perpetua and Felicitas that provide the reader with insight into a martyr's authority as well as their significance for the development of Christianity. Third, I will examine Perpetua's brother's reference to her ability to ask for a vision. Fourth, I will examine Perpetua's acknowledgement

\footnotetext{
${ }^{1}$ A version of this paper was presented at the Medieval and Early Modern Institute's sixth annual interdisciplinary Graduate Student Colloquium, "Martyred Bodies and Religious Communities in Medieval and Modern Europe," on February 26-27, 2010 at the University of Alberta.

${ }^{2}$ Ross Shephard Kraemer, Her Share of the Blessings (New York: Oxford University Press, 1992); Elisabeth Schüssler Fiorenza, In Memory of Her: A Feminist Theological Reconstruction of Christian Origins (New York: Crossroad, 2002); Margaret Y. MacDonald, Early Christian Women and Pagan Opinion: The Power of the Hysterical Woman (New York: Cambridge University Press, 1996).
} 
of her authority and privileges as described in her visions. Fifth, I will examine "the power of martyrdom" and the perceived leadership qualities of confessors. Finally, I will examine how Perpetua's privileges extend from the divine realm into the earthly realm. Specifically, I will examine how Perpetua's impending martyrdom provides her with the "power of the keys" where she is granted the status of a minister.

Though there is scholarly debate surrounding the extent to which early Christians were persecuted, textual evidence proves that at least some Christians were martyred by Roman authorities. ${ }^{3}$ Textual evidence indicates that in some cases, early Christians sought martyrdom and willingly confessed in order to achieve their goal. Though the term martyrdom has commonly been associated with individuals who die a heroic death, the use of this word only begins to appear in Christian literature after The Martyrdom of Polycarp (approximately 155-160 C.E.). This text provides modern readers with the first example of a Christian who died because he refused to relinquish his Christian beliefs. After the arrest and execution of Polycarp, the terminology of martyrdom became associated with conviction and the preference to die a violent death as opposed to denying the Christian faith to appease the authorities. ${ }^{4}$

In his examination of Jewish and Christian martyrdom, Boyarin defines martyrdom as a "response to complex social, religious, and political pressures, and the date and the

\footnotetext{
${ }^{3}$ Christians experienced sporadic persecution between the middle of the first century to the fourth century C.E.. "By the late second century, some Christian communities experienced [...] persecutions resulting in martyrdoms" (Salisbury 1997: 1, 80). De Ste. Croix's article, "Why were the Early Christians Persecuted?," examines the automatic and sporadic martyrdom of Christians from the point of view of early Christians. De Ste. Croix also examines the importance of public opinion in the development of Christian persecution $(2006: 106,121)$. Of interest for the examination of the martyrdom of Perpetua is the edict issued by Septimius in 202 C.E. which outlawed conversion to Christianity (Salisbury 1997: 22).

${ }^{4}$ Jan Willem van Henten and Friedrich Avemarie, Martyrdom and Noble Death: Selected Texts from Graeco-Roman, Jewish and Christian Antiquity (New York: Routledge, 2002), 2-5.
} 
circumstances of its making are still the subject of a lively debate." ${ }^{, 5}$ It is therefore necessary to examine the persecution of early Christians within historical context. Early Christians were charged with refusing to worship the Roman gods, not sacrificing to the gods on behalf of the emperor and not obeying the Roman authorities or magistrates. ${ }^{6}$

It was not so much the positive beliefs and practices of the Christians which aroused pagan hostility, but above all the negative element in their religion: their total refusal to worship any god but their own. The monotheistic exclusiveness of the Christians was believed to alienate the goodwill of the gods, to endanger what the roman called the pax deorum [...] and to be responsible for disasters which over took the community. ${ }^{7}$

Because Christianity was a monotheistic religion that would not permit the worship of other deities, the Christian religion caused fears within the Roman pagan communities. Public opinion, anxieties and superstitions could result in the persecution of early Christians. Because the Roman authorities required individuals to demonstrate loyalty to the state and their religions, some Christians had preferred martyrdom to denying Christianity. Therefore, martyrdom can be interpreted as a choice of religion over state. For some early Christians, martyrdom was perceived as a way to life rather than a way to death. ${ }^{8}$ As such, early Christian martyrdom can also be interpreted as a response to the Roman persecution of the Church.

${ }^{5}$ Daniel Boyarin, Dying for God: Martyrdom and the Making of Christianity and Judaism (California: Stanford University Press, 1999), 94.

6 G. E. M. De Ste. Croix, "Why Were the Early Christians Persecuted?" in Christian Persecution, Martyrdom, and Orthodoxy, ed. Michael Whitby and Joseph Streeter (New York: Oxford University Press, 2006), 112, 121, 124. De Ste. Croix also refers to false charges against early Christians including cannibalism and incest. However, he is quick to prove that such charges were constructed in order to portray Christians as immoral people and inflame public opinion (2006: 128-129).

7 Ibid., 133-134.

${ }^{8}$ Mary Ann Rossi, "The Passion of Perpetua, Everywoman of Late Antiquity," in Pagan and Christian Anxiety: A Response to E. R. Dodds, ed. Robert C. Smith and John Lounibos (New York: University Press of America, 1984), 62. 
Within the Greco-Roman context, self-martyrdom was perceived as empowering the individuals who sought death and provided the martyr with value. ${ }^{9}$ Carole Straw astutely argues that Christian confessor-martyrs believed that their actions transcended Roman culture as well as permitted them to die honourably, heroically and with a guarantee of salvation. ${ }^{10}$ It was assumed during this period that those who had chosen to suffer were not "forced to die" because death was chosen by the martyr. ${ }^{11}$ Furthermore, martyrdom was perceived as a special type of death that exalted God and in turn exalted the martyr. ${ }^{12}$ As such, martyrdom reinforced the notion that life on earth was temporary while the life obtained in or after death was dignified, glorious and permanent. "Perpetual happiness is the reward after their victory" over the Roman authorities. ${ }^{13}$

Though martyrdom and self-martyrdom offered individual personal gains, the early Christian community also benefitted from the martyrs' deaths. The deaths of the martyrs “amplified God's stature on this earth; they bore witness to his heavenly grandeur as Creator, and they sanctified his name." ${ }^{14}$ Obedient martyrdom demonstrated to the Christian community that God could be trusted: martyrs instantly achieved salvation instantly because of their sacrifice. This characteristic of martyrdom demonstrates that there was a form of give and take relationship within martyrdom where one sacrificed the self for God in order to reach heaven. Of particular interest is The Writing to Diognetus where Christians are depicted as having contempt for death: “(Don't you see) that they are thrown to the wild beasts to make them deny their Lord and that

9 Carlin Barton, "Honor and Sacredness in the Roman and Christian Worlds," in Sacrificing the Self: Perspectives on Martyrdom and Religion, ed. Margaret Cormack (New York: Oxford University Press, 2002), 26.

${ }^{10}$ Carole Straw, "A Very Special Death: Christian Martyrdom in its Classical Context," in Sacrificing the Self: Perspectives on Martyrdom and Religion, ed. Margaret Cormack (New York: Oxford University Press, 2002), 39-57.

${ }^{11}$ Ibid., 41.

12 Straw, "A Very Special Death," 49; van Henten and Avemarie, Martyrdom and Noble Death, 91.

13 Van Henten \& Avemarie, Martyrdom and Noble Death, 100.

${ }^{14}$ Straw, “A Very Special Death,” 49. 
they are not being defeated? Don't you see that the more of them are punished, the larger the number of others grows?" 15 This letter proves that martyrdom served as a tool to strengthen the early Christian community as well as provided hope for the community. In his apologies, Tertullian reinforces the notion that martyrdom will only serve to strengthen and expand the Church: "Crucify us, torture us, condemn us, rub us out, but your tortures accomplish nothing. We become more numerous the more you mow us down." 16 This literature presents martyrdom as honourable and desirable. Furthermore, this literature demonstrates that the execution of Christians did not hinder the development of the community but served as an encouragement. Salisbury argues that proto-martyrs performed certain actions prior to their martyrdom in order to strengthen the community. Such acts would include Saturus' gift of the bloody ring to the guard. ${ }^{17}$ This interpretation suggests why some early Christians, including Perpetua, sought martyrdom fervently. ${ }^{18}$ This interpretation also indicates why members of the early Christian community held martyrs, proto-martyrs and confessors in high regards.

At the opening of The Martyrdom of Perpetua and Felicitas, ${ }^{19}$ before the author begins Perpetua's passio, the reader is informed of the important role that martyrs have in the development of Christianity. The author states that ancient deeds "were a proof of God's favour

15 James Donaldson and Alexander Roberts, "The Epistle of Mathetes to Diognetus," in Ante Nicene Fathers, Vol. 1, ed. Alexander Roberts, James Donaldson, and A. Cleveland Coxe (New York: Christian Literature Publishing Co., 1885), 7.7-7.9. Revised and edited for New Advent by Kevin Knight. http://www.newadvent.org/fathers/0101.htm.

16 Tertullian, Apol. 50.13, quoted in Carole Straw, "A Very Special Death," 39-57.

${ }^{17}$ Joyce E Salisbury, Perpetua's Passion: The Death and Memory of a Young Woman (New York: Routledge, 1997), 147.

${ }^{18}$ Throughout the text, Perpetua's martyrdom is presented as a desired goal: the text never suggests that Perpetua sought to escape martyrdom or feared death. When Hilarianus passed sentence on the prisoners, they "returned to prison in high spirits" (115). As they marched into the amphitheatre, they did so joyfully "as though they were going to heaven, with calm faces, trembling, if at all, with joy rather than fear" (125-127). The author re-enforces the martyrs' desire for death by including a reference to Saturninus' intentions. "For whenever they would discuss among themselves their desire for martyrdom, Saturninus indeed insisted that he wanted to be exposed to all the different beasts" (127). The author's use of "they" would have included Perpetua among the other prisoners.

19 Herbert Musurillo, The Acts of the Christian Martyrs (Oxford: Clarendon Press, 1972), 106-131. 
and achieved the spiritual strengthening of men as well." The author's interpretation of martyrdom and the significance of the martyrs' importance within early Christianity reflect the commonly held beliefs that have been examined. The author then proceeds to state that "recent examples $[\ldots]$ will one day become ancient and needful for the ages to come, even though in our own day they may enjoy less prestige because of the prior claim of antiquity." 20 The author's claim that recent examples of martyrdom are "proof of God's favour" and "will one day become ancient" is significant when examining the leadership and authority of the martyrs within this specific text. First, the author provides his text with authority by arguing that the passio has the same value as Scripture. Furthermore, the author argues that like the ancient Scriptures, this authoritative text will gain the prestige it deserves when it becomes ancient. The introduction sets the tone for the rest of the passio. I suggest that the introduction reveals a significant insight into the nature of Perpetua's leadership and authority. By arguing that this text is authoritative and by demonstrating that the Christian martyrs have or will have authority, influence and a lasting impact and importance within Christianity, the author also argues that Perpetua's account is authoritative. Second, by acknowledging the purpose of writing this text, the author informs the readers about the importance of martyr stories. The contemporary texts "were set forth in writing precisely that honour might be rendered to God and comfort to men by the recollection of the past through the written word." 21 This statement suggests that contemporary martyrs will be remembered: they hold and will continue to hold importance in the Christian community. Furthermore, like the ancients, these contemporary martyrs will also help strengthen the faith and spirituality of other individuals. The examples that the martyrs in The Martyrdom of Perpetua and Felicitas will provide hope and establish ideals much like the other martyrs of the period.

${ }_{20}^{20}$ Musurillo, The Acts of the Christian Martyrs, 107-109.
${ }^{2}$ Ibid, 107-109. 
The author brings The Martyrdom of Perpetua and Felicitas full circle at the end of the text when he once again refers to the more general importance of contemporary martyrs. "And any man who exalts, honours, and worships his glory should read for the consolation of the church these new deeds of heroism which are no less significant than the tales of the old." ${ }^{22}$ Like the introduction of the text, Perpetua's importance and authority are asserted because she is a contemporary martyr. I suggest that the majority of the passio should be read in light of this assertion of authority. It is therefore possible to examine The Martyrdom of Perpetua and Felicitas as describing Perpetua's leadership and proving her Scripture-like authority. This assertion demonstrates that the author claims that the passio is virtually another Scripture or a continuation of the biblical narrative. ${ }^{23}$ This assertion is supported by the examination of martyrdom literature where the martyrs were depicted as ideals within the Christian community to be emulated. However, in this case, the author provides the reader with information about the power of Perpetua's authority. It is during the author's description of the visions that the nature of Perpetua's authority is revealed.

In order to properly examine the nature of Perpetua's authority, it is necessary to briefly examine a few specific examples of Perpetua's leadership within her group of fellow confessors and with her brother. The author of The Martyrdom of Perpetua and Felicitas never explicitly states that Perpetua instructed the other martyr-confessors during their imprisonment. However, by interpreting the incidental evidence, it is possible to gain insight into some of their religious conversations and the importance attributed to specific forms of instruction and leadership.

Returning once again to the introduction of the text, the author states that "we hold in honour and acknowledge not only new prophesies but new visions as well, according to

22 Ibid, 131.

23 John Kitchen, interview by author, Edmonton, 24 November 2009. 
promise.” ${ }^{24}$ By including new prophesies and new visions in his argument for the authority of this text, the author argues for the authority and honour of Perpetua's prophecies and visions. The fact that Perpetua can receive divinely promised visions, as suggested in the introduction, proves to the reader that she holds a God-sanctioned authority that she fulfills. Furthermore, the Montanist community was a prophetic movement where exorcism, visions, ecstasy, glossolalia and foreknowledge were key manifestations of the religiou s movement. ${ }^{25}$ Montanist, Priscilla and Maximilla, the Prophets of the New Prophecy, expounded the importance of prophecy. "The New Prophecy believed in the outpouring of the Spirit and the appearance of new, authoritative prophecy which brought fresh disciplinary demands to the churches." 26 The importance that the Montanist community placed on the reception of visions suggests that Perpetua would have been held in high esteem because of her perceived connection with God. In the ancient world, it was believed that visions originated from a source outside of the dreamer: the visions were granted and delivered by God. ${ }^{27}$

The author describes several visions as experienced by Perpetua and Saturus in the passio. Given the importance and honour that the author attributes to visions and prophecy, I suggest that it is likely that both Perpetua and Saturus would have discussed their visions and prophesied at length with their fellow prisoners. Once the group of confessors is imprisoned, Perpetua's brother says to her, "Dear sister, you are greatly privileged; surely you might ask for a vision to discover whether you are to be condemned or freed." Perpetua responds that she will ask for a vision because she knows that she can "speak with the Lord." 28 This request is

\footnotetext{
${ }^{24}$ Musurillo, The Acts of the Christian Martyrs, 107.

${ }^{25}$ Christian Trevett, Montanism: Gender, Authority and the New Prophecy (New York: Cambridge University Press, 1996), 86-95.

${ }^{26}$ Trevett, Montanism, 3.

27 Salisbury, Perpetua's Passion, 93.

${ }_{28}$ Musurillo, The Acts of the Christian Martyrs, 111.
} 
significant for the examination of the nature of Perpetua's authority for two reasons. First, the vision demonstrates that Perpetua has the ability to contact the Lord. Her response to her brother's request suggests that she expected to have visions. ${ }^{29}$ Second, the fact that Perpetua's brother asks Perpetua to seek a vision seems to insinuate that he is also looking for an answer and suggests that the visions and the interpretations of the visions would be shared. This statement is supported by the value that is placed on visions by the New Prophecy. Furthermore, the fact that another believer asks Perpetua to request a vision suggests that either Perpetua was a leader that the other prisoners and believers looked to for guidance and prophecy or she had "a better connection" with God. In her examination of Montanism, Trevett argues that "it is not remarkable that one who was of 'Prophetic' tendency should be sufficiently honoured to have his writings studied by the faithful." ${ }^{30}$ Both male and female prophets acquired fame within Montanism and the prophecies were perceived as inspirational to their followers. Trevett's argument suggests that individuals like Perpetua would have been sought after because of their ability to receive divine prophesies.

It is no wonder that the author of The Martyrdom of Perpetua and Felicitas holds visions in high esteem and Perpetua's brother refers to the ability to ask for a vision as a privilege: the dream world provides Perpetua with direct access to the divine world. Therefore, Perpetua's authority and leadership is based on her direct connection with the heavenly realm. The visions that proto-martyrs received were always perceived as authoritative and divine. ${ }^{31}$ Furthermore, Perpetua's positive response to her brother's request proves that she is confident in her abilities to acquire a vision: she acknowledges her power and authority. Perpetua's ability to seek and receive a vision, as examined within the passio and its historical Montanist context, demonstrates

29 Trevett, Montanism, 182.

30 Trevett, Montanism, 34.

31 Salisbury, Perpetua's Passion, 97. 
that she is recognized as an authority by her fellow Christians, is granted the capability to access the divine and is sought after by other believers for guidance and prophecy.

The author of The Martyrdom of Perpetua and Felicitas provides the reader with another vision that demonstrates Perpetua's ability to receive and interpret visions. While praying with her fellow prisoners, Perpetua unexpectedly remembers her deceased brother Dinocrates and takes the opportunity to pray for him. "At once I realized that I was privileged to pray for him. I began to pray for him and to sigh deeply for him before the Lord." 32 Perpetua proceeds to have a vision while asleep and realizes that her brother is suffering. Instead of despairing over his situation, she is "confident that [she] could help him in his trouble. [...] And [she] prayed for [her] brother day and night with tears and sighs that this favour might be granted [to her]. ${ }^{33}$ Like the terminology her brother used for his request, Perpetua refers to her privilege and her ability to contact God. Again, Perpetua acknowledges her power and authority by stating that she was confident that she could help her brother. In this case, Perpetua further explores the nature of her privilege by stating that she prayed, sighed deeply and wept that God would grant her a favour. In her next vision, she realizes that her actions were successful and that her brother has "been delivered from his suffering." ${ }^{34}$ This passage demonstrates that Perpetua has been given the ability to heal and relieve suffering through intercession. Perpetua's privilege entails the ability to seek the favour of restoration directly through God. ${ }^{35}$

${ }^{32}$ Musurillo, The Acts of the Christian Martyrs, 115.

${ }^{33}$ Ibid., 117.

34 Ibid., 117.

${ }^{35}$ Marie-Louise von Franz and Aviad Kleinberg argue that this vision represents unresolved psychological issues within Perpetua's psychological development. Kleinberg claims that Perpetua's personal anxieties and fears about death and torture are revealed through this vision, see Flesh Made Word: Saints' Stories and the Western Imagination (Massachusetts: The Belknap Press, 2008), 71. Though valuable for understanding Perpetua's possible state of mind, this psychological interpretation fails to examine the historical, social and textual circumstances and evidence. Furthermore, Perpetua's actions in the passio suggest that she adamantly seeks martyrdom. 
While the majority of The Martyrdom of Perpetua and Felicitas focuses on Perpetua, the author also includes Saturus' vision in the passio. While this vision did not appear to Perpetua, the message of the vision is pertinent to understanding her authority and power within her community. In Saturus' vision, four angels react favourably to Perpetua's presence. The angels paid Perpetua and Saturus "homage and said to the other angels in admiration: 'Why, they are here! They are here!"”36 The four angels that were carrying Perpetua and Saturus proceeded to grow fearful of them and set them down. In Saturus' vision, he and Perpetua are recognized and given a special status by angels. Saturus and Perpetua are acknowledged as significant believers: even those who have reached the Gate of Life recognize the sacrifice they are about to make. Perpetua and Saturus then walk into an open area where they are met by other martyrs. "There we met Jucundus, Saturninus, and Artaxius, who were burnt alive in the same persecution, together with Quintus who had actually died as a martyr in prison." ${ }^{37}$ This vision suggests that Christian martyrs will be rejoined in heaven when they have received what God had promised them. This group of individuals has achieved an elite status that is granted to confessor-martyrs: Christians who have died from natural causes are not included in this group. Again, this group of martyrs is indeed privileged.

After meeting and greeting the Lord, they

went out and before the gates we saw the bishop Optatus on the right and Aspasius the presbyter and teacher on the left, each of them apart and in sorrow. They threw themselves at our feet and said: "Make peace between us. For you have gone away and left us thus." And we said to them: "Are you not our bishop, and are you not our presbyter? How can you fall at our feet?"38

\footnotetext{
${ }^{36}$ Musurillo, The Acts of the Christian Martyrs, 121.

37 Ibid.

${ }^{38}$ Ibid., 121-123.
} 
In this circumstance, two individuals with leadership positions within the earthly Church are seeking the intercession of Perpetua and Saturus: they appear to have a problem that cannot be resolved with earthly solutions. Though the bishop and the presbyter's problems were not resolved due to the interruption of angels, this passage indicates that martyrs and proto-martyrs are given a status that is elevated beyond that of clerical authorities. The privilege of heavenly intercessor has been extended into the earthly realm where martyr-confessors can restore and forgive people within their Christian community.

In his examination of the authorship of The Martyrdom of Perpetua and Felicitas, E.R. Dodds presents a convincing argument that the different portions of the passio have "unequal value. ${ }^{, 39}$ Based on the nature of the visions and the stylistic elements of the pieces of the document, Dodds argues that while Perpetua's visions are genuine, Saturus' vision is a later addition. ${ }^{40}$ Obviously, this analysis of the passio grants validity to the nature of Perpetua's authority and her ensuing influence within her Christian community. An examination of the impact of the authorship of Saturus' vision requires further examination. Though at first glance, an argument that denies the genuineness of Saturus' vision would appear to deny the value of Perpetua's scripture-like authority as described in this vision, one can also argue that this later addition further adds to the honour that was attributed to Perpetua by her Christian community. If it is the case that Saturus' vision was a later interpolation, this later addition informs us that the author and audience recognized Perpetua as receiving privileges that placed her above earthly

39 E.R. Dodds, Pagan and Christian in an Age of Anxiety: Some Aspects of Religious Experience from Marcus Aurelius to Constantine (Cambridge: Cambridge University Press, 1965), 48.

${ }^{40}$ Ibid., 47-53. The authorship of The Martyrdom of Perpetua and Felicitas as well as the different portions of the text is highly debated. Dodds argues for the validity of Perpetua's diary based on the simple style, the strong possibility that the diary was written in Greek rather than Latin, the lack of marvels, the nature of her dream-like dreams as well as the request for the visions. Furthermore, Dodds argues that it is unlikely that a hagiographer or forger would include personal dreams where Perpetua encounters her dead brother or where she is transformed into a man (47-53). 
religious figures and granted her with direct access to the divine realm. As such, it was expected by this early Christian community that proto-martyrs received these privileges.

Many scholars believe that Perpetua belonged to the Montanist community which approximately originated between $165-170 \mathrm{CE} .^{41}$ An examination of a few central beliefs of the "New Prophecy" will help unravel why or how Perpetua was granted a divinely appointed position within her Christian community. One of the central themes in Montanism was the expectation and hope for an imminent end of the earthly world. In his examination and interpretation of two New Prophecy oracles, Tertullian states that believers should be "exposed to the public $[\ldots]$. Power comes when you are seen by humans...Do not wish to die in bed or in miscarriages or gentle fevers, but in martyrdom in order that he who has died for you might be glorified." 42 Tertullian's religious instruction for believers is significant for understanding the nature of Perpetua's leadership in both the heavenly and earthly realms. First, Tertullian grants divine authority to the individuals that received the divine revelation that led to this New Prophecy. Because prophecy, according to the oracles, can lead to the glorification of Jesus and Christianity, it is not difficult to comprehend why prophets and prophetesses were influential and powerful within their Christian community. Tertullian, though himself a leader within the Church, grants those who had visions and prophesies a significant amount of authority: it is the prophets and prophetesses that kept the community vibrant with new instructions, insights and glorification. Tertullian's instruction on the importance of oracles, visions and prophesies

${ }^{41}$ In her book, Montanism: Gender, Authority and the New Prophecy, Christine Trevett examines the relationship between Montanism, Perpetua and the redactor of the passio. She argues that Perpetua and her fellow prisoners were likely among "the first-fruits of the Prophecy in Africa" (177). Salisbury is more hesitant to argue that Perpetua and her fellow prisoners were Montanists. However, she states that at the minimum, elements in the passio resemble Montanist beliefs and echo theologies from the New Prophecy. She is certain that the text, if not composed by the martyrs, was written and influenced by later Montanists (157-158).

${ }^{42}$ Frederick Klawiter, "The Role of Martyrdom and Persecution in Developing the Priestly Authority of Women in Early Christianity: A Case Study of Montanism," Church History 49 (1980): 253. 
supports the statement in the introduction of The Martyrdom of Perpetua and Felicitas where the author argues that all individuals who receive visions are granted Scripture-like authority. ${ }^{43}$

Second, in an obvious manner, Tertullian claims that Christians belonging to the Montanist community were expected to maintain and confess their beliefs during persecution. The incidental evidence behind Tertullian's instruction suggests that some members of the Montanist community denied their faith in order to avoid imprisonment and martyrdom. Tertullian's interpretation of the oracles speaks directly against individuals who deny their faith in order to save their lives. "God's will was that a Christian come forth publicly, witness to the faith and voluntarily hand him or herself over to the authorities." ${ }^{44}$ Tertullian states that it is better for an individual to die a martyr's death than to die as a result of natural causes.

It was previously stated that members of the Montanist community held high eschatological expectations. Because they believed that the end of the world was imminent, it was not uncommon for some Montanists to desire martyrdom in order to access the kingdom of heaven. Klawiter argues that the New Prophecy was easily distinguishable from other early Christian groups because of its promotion of voluntary martyrdom. ${ }^{45}$ Proof for these arguments can be seen within The Martyrdom of Perpetua and Felicitas. Throughout the text, Perpetua's martyrdom is presented as a desired goal: the text never suggests that Perpetua sought to escape martyrdom or feared death. When Hilarianus passed sentence on the prisoners, they "returned to prison in high spirits." 46 As they marched into the amphitheatre, they did so joyfully "as though they were going to heaven, with calm faces, trembling, if at all, with joy rather than fear." 47 The author re-enforces the martyrs' desire for death by including a reference to Saturninus'

${ }^{43}$ Musurillo, The Acts of the Christian Martyrs, 107-109.

44 Klawiter, "The Role of Martyrdom and Persecution," 253.

45 Ibid., 254.

${ }^{46}$ Musurillo, The Acts of the Christian Martyrs, 115.

${ }^{47}$ Ibid., 127. 
intentions. "For whenever they would discuss among themselves their desire for martyrdom, Saturninus indeed insisted that he wanted to be exposed to all the different beasts." 48 The author's use of "they" would have included Perpetua among the other prisoners. Tertullian's interpretation of the oracles is also significant for a thorough understanding of The Martyrdom of Perpetua and Felicitas because he includes women in the instruction to seek martyrdom. The opportunity for martyrdom is not restricted to the male gender: it is better for women to die in martyrdom while glorifying Jesus than to die in miscarriage while fulfilling the expected gender roles of the period. The instruction for all individuals regardless of gender to seek voluntary martyrdom provided women with an opportunity to achieve a form of gender equality in their deaths.

Contemporary conceptions of martyrdom in general, high eschatological expectations as well as the goal to confess faith within the New Prophecy explain why Montanist martyrs were able to achieve positions of authority within their early Christian community. This argument is heavily supported by Eusebius' Letter of the Churches of Vienne and Lyons. In this text, Eusebius argues that imprisoned confessors have the ability to exercise "the power of martyrdom." 49

For they had this very conflict with him, the devil, on account of their genuine love, in order that the Beast being choked, might vomit forth those whom he thought he had already swallowed. For they assumed no airs of superiority over the fallen, but with those things in which they themselves abounded they aided the needy, displaying towards them the compassion of a mother. And pouring out many tears for them to the Father, they begged life; and he gave it to them, and they shared it with their neighbours. ${ }^{50}$

48 Ibid., 117.

49 Klawiter, "The Role of Martyrdom and Persecution," 255.

${ }^{50}$ Peter Kirby, "Letter from Vienna and Lyons," in Early Christian Writings (2 February 2006), 5.40-41. http://www.earlychristianwritings.com/viennalyons.html. 
The "power of martyrdom" that was granted to proto-martyrs granted the prisoners the capability to intercede on behalf of Christians who had denied their faith or failed to confess. Essentially, imprisoned confessors were given the privilege of the authority to forgive deniers. Though Eusebius makes a clear distinction between confessors and martyrs in the Historia Ecclesia, he attributes this power to all individuals who are imprisoned because of their Christian faith. Klawiter further expounds on this idea by stating that "it is well known that in early Christianity, martyrs awaiting their death could exercise and manifest extraordinary power. They even had the power of the keys, that is, the power to forgive the sins of those who had denied the faith and were therefore thought to have lost salvation." ${ }^{51}$ Klawiter astutely translates the "power of martyrdom" into the "power of the keys." It is by praying, shedding tears and prostrating themselves in front of God that confessor-martyrs can access divine grace and restore lapsed individuals or individuals who had denied their faith during persecution back into their Christian community as full members once again. By having and utilizing the compassion of a mother, proto-martyrs figuratively have the keys to the Christian community. The notion of martyrs as intercessors is supported by Peter Brown's use of the patron-client model to examine the cults of the saints. ${ }^{52}$ By acting as intercessors between members of their early Christian communities and

${ }^{51}$ Klawiter, "The Role of Martyrdom and Persecution," 254.

${ }^{52}$ Brown's use of the patron-client model provides insight into the nature of the cult of saints and its attractiveness. By drawing upon the concepts of ancient relationships, Christian writers provided the cult of the saints with a familiar and comforting background. The saint-client relationship was attractive because it was accessible to all Christians and provided them with protection, inspiration and reassurance, see The Cult of the Saints: Its Rise and Function in Latin Christianity. (Chicago: The University of Chicago Press, 1981), 52-53, 101. "In a world so sternly organized around sin and justice, patrocinicum and amicitia provided a much needed language of amnesty" (Ibid., 65). The transmission of the patron-client model into the cult of saints provided Christians with an intimate relationship with which they were familiar. "What we have seen is not the growth of new beliefs within the Christian communities, but the restructuring of old beliefs in such a way as to allow them to carry a far heavier 'charge' of public meaning" (Ibid., 48). 
God, confessor-martyrs are prototypes for Brown's patron-client model. Like saints, confessormartyrs provided those who sought their help with security and assistance.

I suggest that the previously examined vision where Perpetua relieves her dead nonChristian brother's suffering indicates that she has been given "the power of the keys." The author of the passio directly attributes the reconciliation of Perpetua's brother to the Christian community with Perpetua's recognition of her privileges. Furthermore, Perpetua's ability to relieve her dead brother's suffering in her vision indicates that her authority is divinely granted and has been sanctioned by God. ${ }^{53}$ In this circumstance, it is God who recognizes Perpetua's intercession as a confessor-martyr and grants divine grace because of Perpetua's compassion. Perpetua's actions parallel those described by Eusebius in the Historia Ecclesia: "And I was pained when I recalled what had happened to him. At once I realized that I was privileged to pray for him. I began to pray for him and to sigh deeply for him before the Lord." ${ }^{, 54}$ Perpetua continues to pray for her brother until he has been delivered from his suffering: "I was confident that I could help him in his trouble; and I prayed for him every day until we were transferred to the military prison [...]. And I prayed for my brother day and night with tears and sighs that favour might be granted me." 55 Like the martyr-confessors described in Historia Ecclesia, Perpetua has the capacity to aid the needy, pour tears out before God and gain the deniers "life." Perpetua recognizes that her ability to access the divine and restore individuals to the Christian community is a privilege. The "power of the keys" is a privilege given to proto-martyrs because they have maintained and confessed their faith during persecution.

\footnotetext{
${ }^{53}$ Musurillo, The Acts of the Christian Martyrs, 115-117.

${ }^{54}$ Ibid., 115.

${ }^{55}$ Ibid., 117.
} 
Though it is an indirect reference to "the power of martyrdom," her brother's request for a vision also provides evidence for Perpetua's "power of the keys." ${ }^{56}$ During his request, Perpetua's brother states that Perpetua can ask for a vision because she is privileged. Considering that Perpetua had only recently come to believe in the message of Christianity and was only a catechumen when she was arrested, ${ }^{57}$ I suggest that she only received privileges because of her status as a confessor-martyr. I further suggest that the privilege of divine authority granted by God directly led to the privileges that were conferred to the confessor-martyrs by the early Christian community.

By giving Perpetua the power to relieve suffering and provide forgiveness, the author gives her an authority that was previously limited to a bishop-presbyter. ${ }^{58}$ In these circumstances, Perpetua's leadership and authority is exemplified by her bishop-presbyter type actions. This argument is supported by Saturus' vision where Perpetua is approached by a bishop and a presbyter who are feuding. ${ }^{59}$ As was previously stated, these authoritative figures acknowledge Perpetua's divine authority and her power to reconcile: they recognize and accept the "power of the keys." The acceptance of the "power of the keys" by members of the Montanist community, including Church leaders, explains why Perpetua is depicted as a leader and influential individual within the Christian community. Martyrdom itself was perceived as an indication that God had provided an individual with grace and favour. ${ }^{60}$ Because it was believed that confessor-martyrs received the direct support of God, they were honoured and provided with significant leadership roles within their community. Kleinberg elaborates on the nature of this status and argues that "humans are but clay that God can mold into a vessel of honor or of dishonor. [...] She has

\footnotetext{
${ }^{56}$ Ibid., 111.

${ }^{57}$ Ibid., 109.

${ }^{58}$ Klawiter, "The Role of Martyrdom and Persecution," 254.

${ }_{59}$ Musurillo, The Acts of the Christian Martyrs, 121-123.

${ }^{60}$ Boyarin, Dying for God, 102.
} 
become a vessel of honor. She does not wish to change." ${ }^{\text {, } 1}$ There is a direct relationship between Perpetua's divinely supported privileges and her honoured privileged role within her community: the "power of martyrdom" or the "power of the keys" led Perpetua to power within her community. Because God has molded her into a vessel of honour, she is honoured by her Christian community.

Perpetua's access to visions and the "power of the keys" provides general information about women and leadership. Perpetua's biological gender does not exclude her from the opportunity to receive visions, act as a leader or access the divine realm. ${ }^{62}$ "It is highly probable that from the beginning of Montanism, women were permitted to rise to ministerial status through their role as confessor-martyrs in the early Christian Church."63 In her examination of Montanism, Trevett argues that women within the New Prophecy were able to reach a more public participation than their Catholic counterparts because of differences in Church structure and ideals. ${ }^{64}$ All individuals, regardless of gender, were encouraged to be full public disciples and martyrs. This argument is supported by the author's reference to Acts 2:17-18 in the introduction of The Martyrdom of Perpetua and Felicitas. "In the last days, God declares, I will pour out my Spirit upon all flesh and their sons and daughters shall prophesy [...]." ${ }^{65}$ By including Perpetua's visions and privileges in his narrative, the author provides a salient example

${ }^{61}$ Aviad Kleinberg, Flesh Made Word, 60.

${ }^{62}$ Because Perpetua receives a vision where she discovers that she is a man, there is debate regarding the nature of her gender as well as the influence of gender on salvation, access to the divine and leadership. "My clothes were stripped off, and suddenly I was a man. My seconds began to rub me down with oil" (Musurillo, The Acts of the Christian Martyrs, 119). While acknowledging the complexity of the issue of Perpetua's gender, I claim that evidence found in the passio indicates that her female physical attributes do not exclude her from the opportunity to access the divine realm regardless of any rejection or acceptance of acceptable gender roles. Kleinberg's text, Flesh Made Word, provides an interesting examination of Perpetua's gender, gender expectations, her transformation, the addition of male qualities and her transformation back to femininity (Ibid., 75-76).

${ }_{63}$ Kleinberg, Flesh Made Word, 251.

${ }^{64}$ Trevett, Montanism, 176 and 184.

${ }^{65}$ Musurillo, The Acts of the Christian Martyrs, 107. 
of the opportunities for men and women to receive visions, prophesize, become confessormartyrs and obtain presbyter-bishop influences within the Christian community.

An examination of her brother's request for a vision as well as the nature of the previously examined visions in The Martyrdom of Perpetua and Felicitas reveals that Perpetua is privileged because her confessor-martyr status provides her with direct access to the divine realm. Furthermore, the visions which I have examined demonstrate that she has achieved a divinely attributed authority which grants her the ability to act as an intercessor and restore members to the Christian community. The largest act of restoration that Perpetua has achieved in the passio is the restoration of her brother to the Christian community. According to her two visions, Perpetua has rescued her deceased brother from his suffering and has provided him with salvation. However, it is evident that the authority which is granted to Perpetua because of her confessor-martyr status is not only limited to the divine realm. Perpetua's recognition of her authority and her leadership actions within her Christian community suggest that she is also privileged with a position of influence within the earthly realm. Perpetua's brother requests that she request a vision because Perpetua is privileged. The bishop Optatus and the presbyter Aspasius seek Perpetua's assistance in reconciliation because she has achieved an authority which extends beyond their earthly powers. The divinely granted "power of martyrdom" or "power of the keys" provided Perpetua with access to God and earthly authority. 


\section{Bibliography}

Barton, Carlin. "Honour and Sacredness in the Roman and Christian Worlds." In Sacrificing the Self: Perspectives on Martyrdom and Religion, edited by Margaret Cormack, 23-38. New York: Oxford University Press, 2002.

Boyarin, Daniel. Dying for God: Martyrdom and the Making of Christianity and Judaism. California: Stanford University Press, 1999.

Brown, Peter. The Cult of the Saints: Its Rise and Function in Latin Christianity. Chicago: The University of Chicago Press, 1981.

De Ste. Croix, G. E. M. “Why Were the Early Christians Persecuted?” In Christian Persecution, Martyrdom, and Orthodoxy, edited by Michael Whitby and Joseph Streeter, 105-152. New York: Oxford University Press, 2006.

Dodds, E. R.. Pagan and Christian in an Age of Anxiety: Some Aspects of religious Experience from Marcus Aurelius to Constantine. Cambridge: Cambridge University Press, 1965.

Donaldson, James and Alexander Roberts. "The Epistle of Mathetes to Diognetus." From Ante Nicene Fathers, Vol. 1, edited by Alexander Roberts, James Donaldson, and A. Cleveland Coxe. New York: Christian Literature Publishing Co., 1885. Revised and edited for New Advent by Kevin Knight. http://www.newadvent.org/fathers/0101.htm.

Fiorenza, Elisabeth Schüssler. In Memory of Her: A Feminist Theological Reconstruction of Christian Origins. New York: Crossroad, 2002.

Kirby, Peter. "Letter from Vienna and Lyons." Early Christian Writings. 2006. 2Feb. 2006. http://www.earlychristianwritings.com/viennalyons.html.

Klawiter, Frederick. "The Role of Martyrdom and Persecution in Developing the Priestly Authority of Women in Early Christianity: A Case Study of Montanism." Church History 49 (1980): 251-61.

Kleinberg, Aviad. Flesh Made Word: Saints' Stories and the Western Imagination. Massachusetts: The Belknap Press, 2008.

Kraemer, Ross Shephard. Her Share of the Blessings. New York: Oxford University Press, 1992.

MacDonald, Margaret Y. Early Christian Women and Pagan Opinion: The Power of the Hysterical Woman. New York: Cambridge University Press, 1996.

Musurillo, Herbert. The Acts of the Christian Martyrs. Oxford: Clarendon Press, 1972.

Rossi, Mary Ann. “The Passion of Perpetua, Everywoman of Late Antiquity.” In Pagan and 
Christian Anxiety: A Response to E. R. Dodds, edited by Robert C. Smith and John Lounibos, 53-86. New York: University Press of America, 1984.

Salisbury, Joyce E. Perpetua's Passion: The Death and Memory of a Young Woman. New York: Routledge, 1997.

Straw, Carole. "A Very Special: Christian Martyrdom in its Classical Context." In Sacrificing the Self: Perspectives on Martyrdom and Religion, edited by Margaret Cormack, 39-57. New York: Oxford University Press, 2002.

Thelwall, S. "Apology." From Ante-Nicene Fathers, Vol. 3, edited by Alexander Roberts, James Donaldson, and A. Cleveland Coxe. New York: Christian Literature Publishing Co., 1885. Revised and edited for New Advent by Kevin Knight. http://www.newadvent.org/fathers/0301.html.

Trevett, Christian. Montanism: Gender, Authority and the New Prophecy. New York: Cambridge University Press, 1996.

Van Henten, Jan Willem and Friedrich Avemarie. Martyrdom and Noble Death: Selected Texts from Graeco-Roman, Jewish and Christian Antiquity. New York: Routledge, 2002.

Von Franz, Marie-Louise. The Passion of Perpetua: A Psychological Interpretation of Her Visions. Toronto: Inner City Books, 2004. 